\title{
Influence of pole number on the characteristics of permanent magnet synchronous motor (PMSM)
}

\author{
S. Raj ${ }^{1}$, R. Aziz ${ }^{2}$, M. Z. Ahmad \\ ${ }_{1,2,3}$ Faculty of Electrical And Electronic Engineering, Universiti Tun Hussein Onn Malaysia (UTHM)
}

\begin{tabular}{l} 
Article Info \\
\hline Article history: \\
Received Jun 1, 2018 \\
Revised Jul 10, 2018 \\
Accepted Jul 25, 2018 \\
\hline
\end{tabular}

\section{Keywords:}

Influence

Motor performance

Permanent magnet

Pole number

Slot pole combination

\begin{abstract}
This paper present the influence of pole number on the characteristics of permanent magnet synchronous motor (PMSM). This study is devoted to construct three different motors with varying pole numbers and investigating its effect on the characteristics of permanent magnet synchronous motor (PMSM). It is a study on an influence of pole numbers on electromagnetic and thermal characteristics of the PMSMs all while maintaining the same motor dimensions, parameters and slot number. The study is conducted to analyse the best slot-pole combination for a given dimension to determine if pole numbers have a role in the motor performance. The analysis for these permanent magnet motors is done via finite element analysis (FEA) in which JMAG Designer software is used. The software is used to analyse the motor performance in terms of cogging torque, speed, power, iron loss, copper loss as well as the efficiency of the motor itself. All three motors were simulated in no load and load condition.
\end{abstract}

Copyright $@ 2019$ Institute of Advanced Engineering and Science. All rights reserved.

\section{Corresponding Author:}

Roziah Aziz,

Faculty of Electrical and Electronic Engineering,

Universiti Tun Hussein Onn Malaysia,

Parit Raja, Batu Pahat, Johor.

Email: roziah@uthm.edu.my

\section{INTRODUCTION}

Studies Studies on electric vehicles are actively pursued as an environment friendly technology as it is becoming important as the possibilities to improve fuel efficiency is higher using regenerated kinetic energy; mainly utilizing electric motors. Electric machines are devices that are used in conversion of electromechanical energy and conversion of electrical energy to mechanical energy by electrical motors can be divided into two; direct current (DC) motor and alternating current (AC) motor [1].

Often used in electric vehicles are the permanent magnet motors as these motors are highly efficient because secondary copper loss does not occur as current induced magnetic field is unnecessary [2-3]. Besides, it has an advantage of making the motor smaller by being able to raise the magnetic flux density [4]. As per basic requirements, electric vehicle drive system requires high efficiency, high torque density as well as constant power at high speed and permanent magnet motor will be suitable in experimenting for these characteristics.

Permanent magnet synchronous motors and synchronous motors basically works the same way and have similar performance characteristics. A standard synchronous motor without field winding and slip rings can be exactly alike in configuration to that of a permanent magnet synchronous motor. Magnetic pole number and line frequency determines the speed of the synchronous motor [5].

When compared to induction motors as in Figure 1, it is also similar but the only difference is that in PMSM, the permanent magnet generates the rotor magnetic field. Substantial air gap magnetic flux produced by the usage of permanent magnet allows the designing of highly efficient permanent magnet motors. 


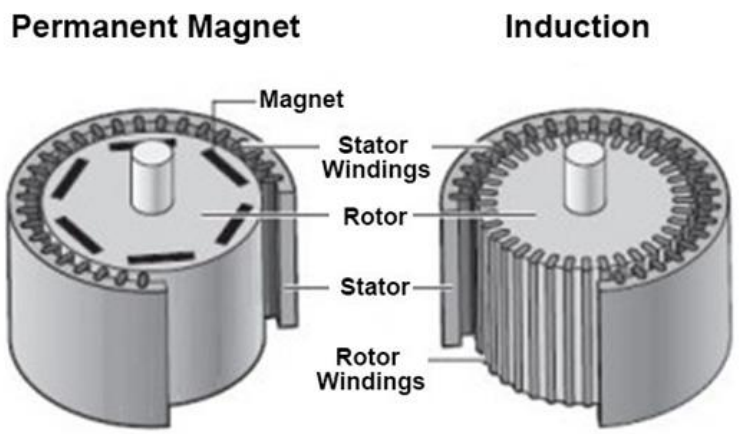

Figure 1. Comparison of permanent magnet motor and induction motor

From Figure 2, we can see the cross section of a basic permanent magnet synchronous motor. It generally has a stationary element also known as stator, an electromagnet, which makes up the outer part of the motor. Soft steel strips make the stator laminations windings in axial air gap machines. Those laminations have teeth slots for the armature windings and its thickness is affected by the cost and armature source voltage frequency. The magnetic path is completed by the yoke of the motor.

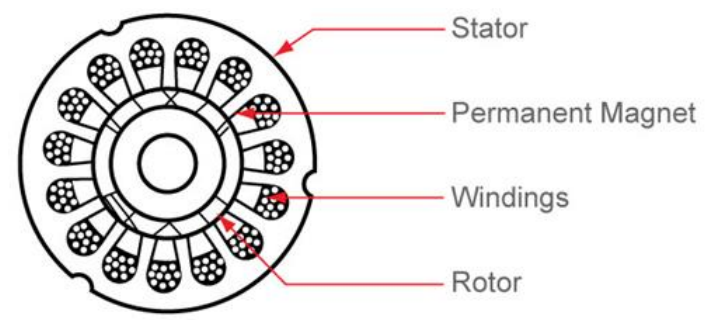

Figure 2. Cross section of simple PMSM

\section{DESIGN RESTRICTIONS AND SPECIFICATIONS}

The relationships between parameters of the motor design are used to study the pole number effect on electromagnetic characteristic of the permanent magnet synchronous motors. These motors have their designs modified to have their electromagnetic characteristics tested at $1500 \mathrm{rpm}$ with the design constraints as in Table 1.

Table 1. Design parameters of proposed PMSMs

\begin{tabular}{lc}
\hline \multicolumn{1}{c}{ Items } & Dimensions \\
\hline Rated speed [rpm] & 1500 \\
Stator diameter [mm] & 260 \\
Rotor diameter [mm] & 156 \\
Number of slots & 36 \\
Number of poles & $4,6,12$ \\
Slot opening [mm] & 2.532 \\
Core back width [mm] & 3.9 \\
Tooth width [mm] & 11 \\
Tooth tang depth [mm] & 3 \\
Gap between magnet [mm] & 1.692 \\
Number of turns of armature coil & 15 \\
\hline
\end{tabular}

The three-phase PMSM motors that were designed are $36 \mathrm{~S}-4 \mathrm{P}, 36 \mathrm{~S}-6 \mathrm{P}$ and the $36 \mathrm{~S}-12 \mathrm{P}$ respectively. They have the same stator pole number with the stated dimension specifications while number of pole is varied from one and the other. The cross-sections of the motors are shown in Figure 3.

JMAG Designer version 14 was used to carry out this study. Data analysis in the form of 2D-FEA are the results obtained in this study. 


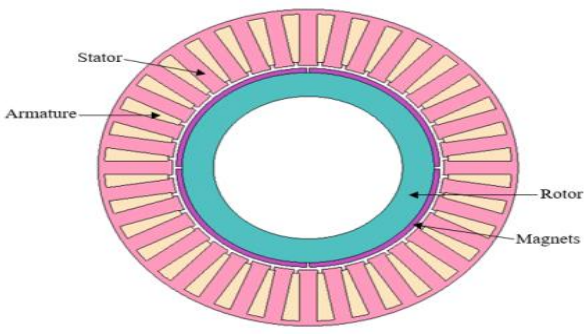

(a)

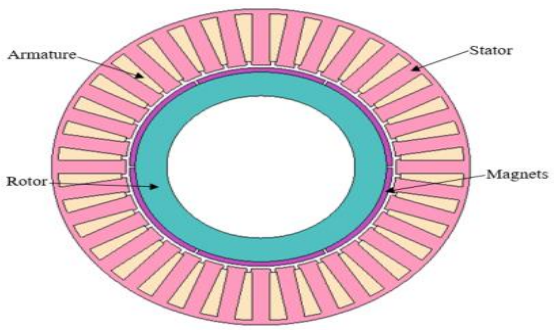

(b)

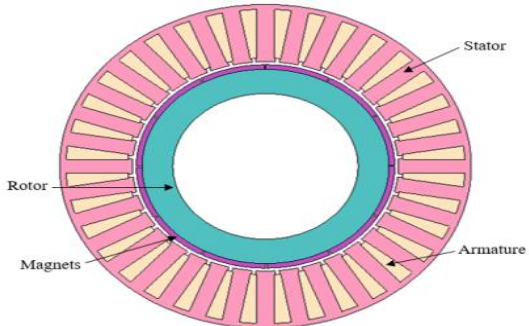

(c)

Figure 3. Finished design of PMSM motors (a) 36S-4P (b) 36S-6P (c) 36S-12P

\section{PERFORMANCE OF 36S-4P, 36S-6P and 36S-12P PMSMs}

\subsection{Armature Coil Operating Principle Analysis}

The operating principle and arrangement of armature coils are verified through the coil test conducted at no load condition. The aim of this test is to validate the operating principle of the designed PMSMs by setting the position of the armature coils. Accordingly, the tests are conducted separately for each coil thus defining the armature coil phases into its conventional three phase system; U, V and W. Figure 4 illustrates the 3-phase flux linkage achievement with separate phase of $120^{\circ}$ apart.

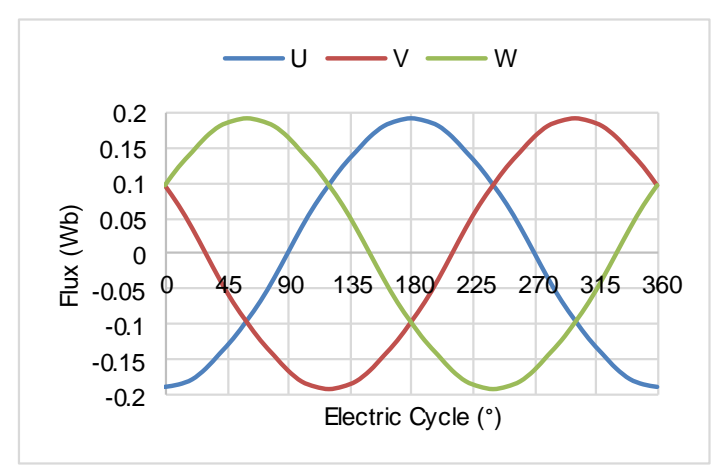

(a)

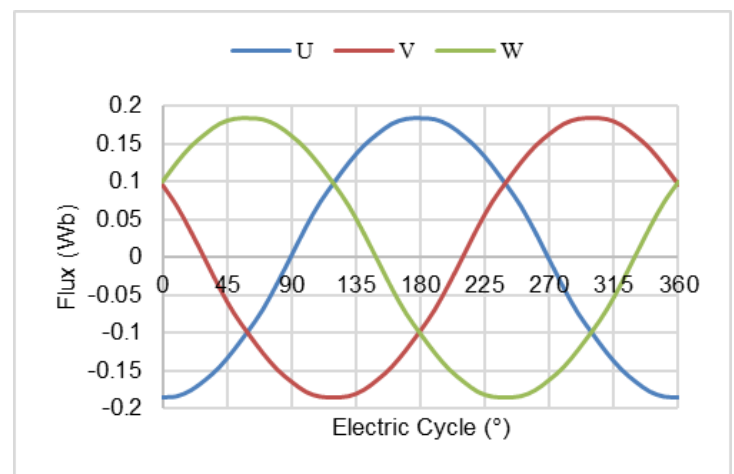

(b)

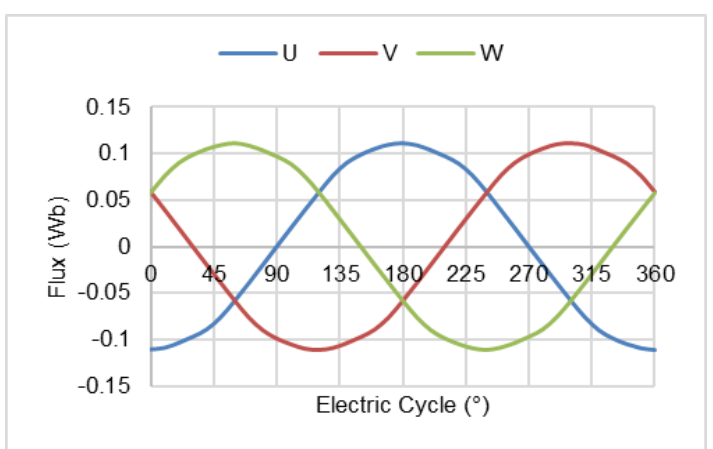

(c) 
Figure 4. Graph of Flux linkage (a) 36S-4P PMSM (b) 36S-6P PMSM (c) 36S-12P PMSM

\subsection{Back -Emf}

Figure 5 shows the back-emf graph the 36S-4P PMSM, 36S-6P PMSM and the 36S-12P PMSM configuration when the motors rotate at a speed of $1500 \mathrm{rev} / \mathrm{min}$. The $36 \mathrm{~S}-4 \mathrm{P}$ conventional PMSM is observed to have an amplitude of $204.11 \mathrm{~V}$ while the proposed 36S-6P PMSM has a peak value of $313.53 \mathrm{~V}$ whose waveform is characterized by degraded harmonics. Meanwhile, the 36S-12P PMSM achieved backemf value of $400.36 \mathrm{~V}$ with a better sinusoidal waveform.

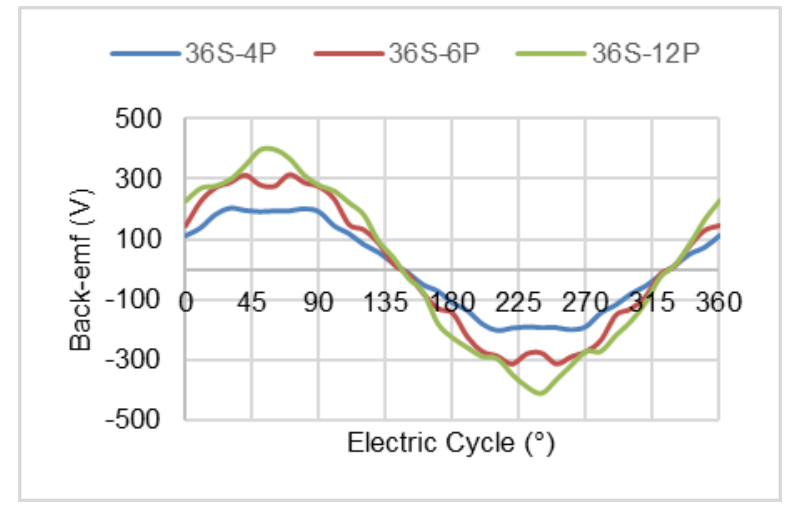

Figure 5. Comparation of back EMF for all three motors

\subsection{Torque versus Armature Current $J_{\mathrm{A}}$}

The torque against armature current density of the motors is conducted by injecting the current varied from $\mathrm{J}_{\mathrm{A}} 5 \mathrm{~A} / \mathrm{mm}^{2}$ to $\mathrm{J}_{\mathrm{A}} 30 \mathrm{~A} / \mathrm{mm}^{2}$ into the FEM coil in order to analyse the pattern of torque behaviour. Simulated results of the 36S-4P, 36S-6P and 36S-12P PMSMs are shown in Figure 6. From the graph, it can be observed that the torque gradually increases as higher value of current is injected. The highest torque is obtained with the maximum armature current density of $30 \mathrm{~A} / \mathrm{mm}^{2}$. The torque values for the $36 \mathrm{~S}-4 \mathrm{P}, 36 \mathrm{~S}-6 \mathrm{P}$ and $36 \mathrm{~S}-12 \mathrm{P}$ motors are recorded as $112.6 \mathrm{Nm}, 187 \mathrm{Nm}$ and $205.4 \mathrm{Nm}$ respectively. It is obvious that the $36 \mathrm{~S}-12 \mathrm{P}$ motor has the highest output torque followed by the $36 \mathrm{~S}-6 \mathrm{P}$ and lastly $36 \mathrm{~S}-4 \mathrm{P}$ PMSM.

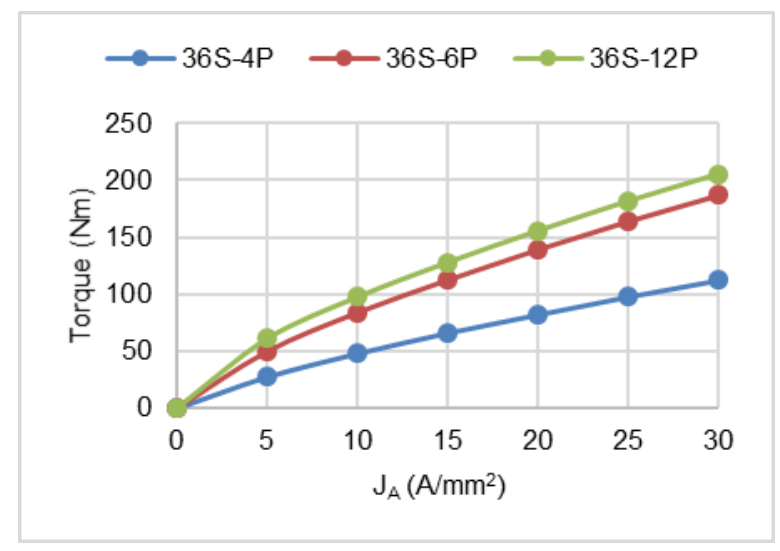

Figure 6. Torque vs various $\mathrm{J}_{\mathrm{A}}$ for different number of poles

\subsection{Torque and Power versus Speed}

The torque and power versus speed characteristics of the designed motors are shown in Figures 7. In each plot, the blue curve represents torque versus speed while the orange line represents the power versus speed curve. Figure 7(a) shows that at base speed of $678 \mathrm{rpm}$, the highest torque of the 36S-4P PMSM is $116.8 \mathrm{Nm}$ at which the power output is $4.15 \mathrm{~kW}$. At the maximum speed of $1800 \mathrm{rpm}$, there is a decline in the output power up to $45 \%$, where the value is $2.3 \mathrm{~kW}$. 
As in Figure 7(b), the 36S-6P PMSM reached a maximum torque of $189.26 \mathrm{Nm}$ at the base speed of $768 \mathrm{rpm}$ and begins to decrease when operated beyond the base speed region due to high iron loss. Furthermore, the power accomplished is $7.6 \mathrm{~kW}$ before decreasing to $2.9 \mathrm{~kW}$ which is about $62 \%$, upon reaching a maximum speed of $1800 \mathrm{rpm}$.

However, the 36S-12P motor as in Figure 7(c), achieved the highest output torque when compared with all three designs. The torque value is $209.5 \mathrm{Nm}$ at a base speed of 960rpm is achieved. The output power peaked at $10.52 \mathrm{~kW}$ and as the speed reached its maximum at $1800 \mathrm{rpm}$, the power gradually reduces about $12.55 \%$ to $9.2 \mathrm{~kW}$.

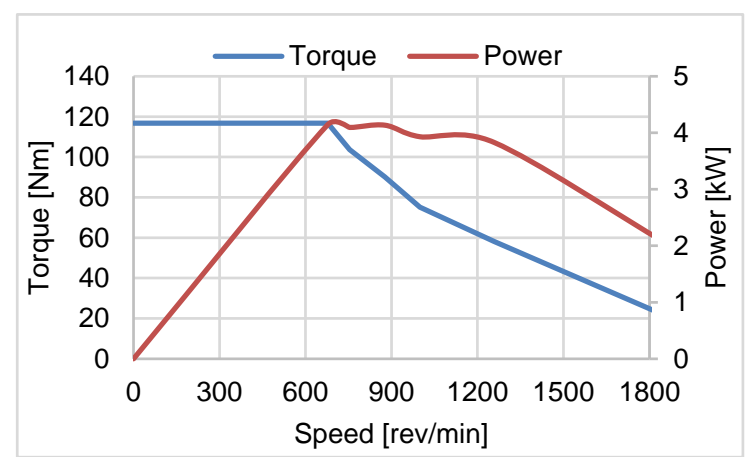

(a)

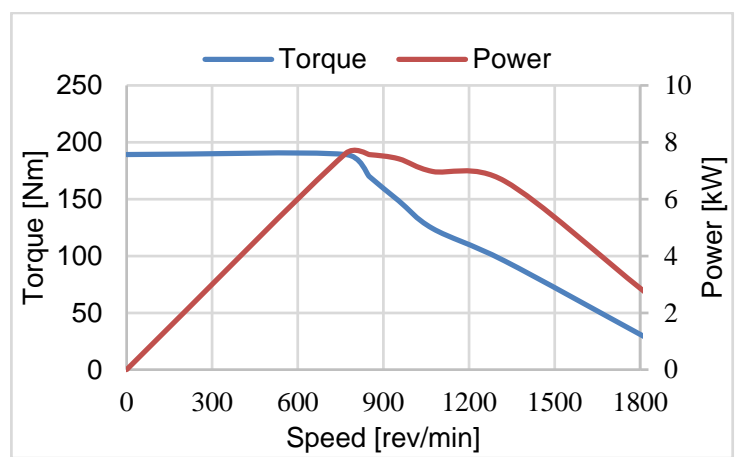

(b)

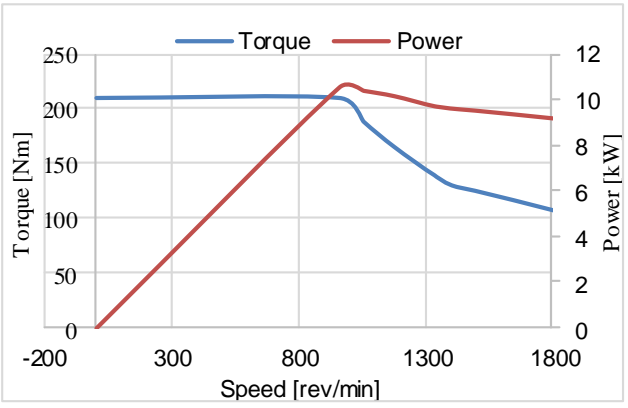

(c)

Figure 7. Torque and power vs speed graph for (a) 36S-4P PMSM (b) 36S-6P PMSM (c) 36S-12P PMSM

\section{CONCLUSION}

Effects of pole number on the electromagnetic characteristics has been evaluated and analyzed. The selected pole number combination that is analyzed are 36S-4P, 36S-6P and 36S-12P PMSMs. The operating principles of all three designs with varying pole number was observed and validated through successful development of design and coil test analysis as well as its performance tested through no load and load analysis. It is evident that the pole number plays a role in determining the efficiency and smoothness of a motor.

\section{ACKNOWLEDGEMENTS}

The authors gratefully acknowledge the contribution of Research Management Center (RMC), Universiti Tun Hussein Onn Malaysia (UTHM), Batu Pahat, Johor, Malaysia for the financial support of this research. This research is partly by RMC under the U850 (Tier 1) Grant.

\section{REFERENCES}

[1] E. Sato, "Permanent magnet synchronous motor drives for hybrid electric vehicles," IEEJ Trans. Electr. Electron. Eng., vol/issue: 2(2), pp. 162-168, 2007.

[2] T. Su and Y.K Sun, "Design of Drive System of Permanent Magnet Synchronous Motor for Hybrid Electric Vehicles," Wei-Te Dianji (Small Spec. Electr. Mach.), vol.37, no.2, pp.36-38, 2009. 
[3] Z.Q. Zhu and D. Howe, "Electrical Machines and Drives for Electric, Hybrid, and Fuel Cell Vehicles," Proc. IEEE, vol. 95, no.4, pp.746-765,2007.

[4] R. Aziz, G.J.Atkinson, "Performance of Automotive Permanent Magnet Machines with Different Sizes, Rare-earth Magnets and Winding Configuration," IEEE $15^{\text {th }}$ International Conference on Environment and Electrical Engineering, Rome, 10-13 June 2015.

[5] L. Qi, F. Tao, W. Xuhui, T. Xiang, L. Ye, and Z. Guangzhen. 2013. "Modeling of the Efficiency MAP of Surface Permanent Magnet Machine for Electrical Vehicles,” pp. 1222-1225.

[6] D. Misu and M. Matsushita. 2014. "Consideration of Optimal Number of Poles and Frequency for High-efficiency Permanent Magnet Motor,” pp. 3012-3017.

[7] L. Wu, R. Qu, D. Li, and Y. Gao. 2015. "Influence of Pole Ratio and Winding Pole Numbers on Performances and Optimal Design Parameters of Surface Permanent Magnet Vernier Machines,” IEEE Trans. Ind. Appl., vol. 9994, no. c, pp. $1-1$.

[8] B. Tian, Q. An, L. Sun, D. Sun, and J. Duan. 2016. "Initial Position Estimation Strategy for a Surface Permanent Magnet Synchronous Motor Used in Hybrid Electric Vehicles," Front. Inf. Technol. Electron. Eng., vol. 17, no. 8, pp. 803-813.

[9] T.D. Kefalas and A. G Kladas, “ Thermal investigation of permanent-magnet Synchronous Motor for Aerospace Applications,” IEEE Trans. Ind. Electron., vol.61, no.8,pp.4404-441,2014.

[10] T. Renyuan, "Research and Development of Rare Earth PM Machine," Elect. Mach. Syst. ICEMS 2001, 2002.

[11] D. Borg- Bartolo, D. Gerada, C. Micallef, A.Mebarki, N.L. Brown, and C.Gerada, "Thermal Modelling and Selection of a High Speed Permanent Magnet Mount Electrical Machine," $6^{\text {th }}$ IET Int. Conf. Power Electro. Mach. Drives (PEMD 2012), pp.B113,2012.

[12] R.Aziz, G.J Atkinson, S. Salimin, "Thermal Modelling for Permanent Magnet Synchronous Machine (PMSM)" International Journal of Power Electronics and Drive System (Ijpeds), 8, 4, UTHM, 1903-1912, (2017).

[13] X.Liu, Q. Lin, and W.Fu,'Optimal Design of Permanent Magnet Arrangement in Synchronous Motors," Energies, vol. 10, no.11, p. 1700,2017.

[14] Munoz, A.R. Liang, F. Degner, “Evaluation of Interior PM and Surface PM Synchronous Machine with Distributed and Concentrated Winding,” Industrial Elecronics, IECON 2008, pp 1189-1193.

[15] M. Cheng, W.Hua, J.Zhang, and W. Zhao, "Overview of Stator Permanent Magnet Brushless Machines," IEEE Trans. Ind. Electron., vol.58, no.11, pp. 5087-5101,2011.

\section{BIOGRAPHIES OF AUTHORS}

Sharveenah Raj is a student in Faculty of Electrical Engineering (FKEE), UTHM. After
graduated from her diploma in Power Electrical Engineering (UTM-2013), she pursued her study
in bachelor Power Electrical Engineering in UTHM. She is currently attached to a company in
Johor Bahru as project engineer. Her research interests are in electrical machine design and
permanent magnet machines.

Influence of pole number on the characteristics of permanent magnet synchronous motor (PMSM) (S. Raj) 